\title{
Effects of Tumor Necrosis Factor- $\alpha$ on Podocyte Expression of Monocyte Chemoattractant Protein-1 and in Diabetic Nephropathy
}

\author{
Choon Hee Chung a, b Jingyi Fan a, d Eun Young Lee ${ }^{a, c}$ Jeong Suk Kang ${ }^{c}$ \\ Seung Joo Lee ${ }^{c}$ Petr E. Pyagay ${ }^{a}$ Charbel C. Khoury ${ }^{a}$ Tet-Kin Yeo ${ }^{a}$ \\ Mark F. Khayat ${ }^{a}$ Amy Wang ${ }^{a}$ Sheldon Chen ${ }^{a, e}$ \\ aDivision of Nephrology/Hypertension, Northwestern University, Chicago, IIl., USA; \\ ${ }^{b}$ Department of Internal Medicine, Yonsei University Wonju College of Medicine, Wonju, \\ and ${ }^{~}$ Department of Internal Medicine, Soonchunhyang University College of Medicine, \\ Cheonan, Korea; ${ }^{d}$ Pediatric Department, Wuhan University School of Medicine, Zhongnan

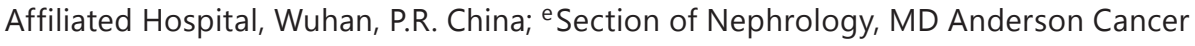 \\ Center, Houston, Tex., USA
}

\section{Key Words}

TNF receptor 2 - Nuclear factor-kappaB Phosphatidylinositol 3-kinase $\cdot$ Akt or protein kinase $B \cdot$ Albuminuria $\cdot$ Diabetic rodent model

\begin{abstract}
Background/Aims: Tumor necrosis factor (TNF)- $\alpha$ is believed to play a role in diabetic kidney disease. This study explores the specific effects of TNF- $\alpha$ with regard to nephropathy-relevant parameters in the podocyte. Methods: Cultured mouse podocytes were treated with recombinant TNF- $\alpha$ and assayed for production of monocyte chemoattractant protein-1 (MCP-1) by enzyme-linked immunosorbent assay (ELISA). TNF- $\alpha$ signaling of MCP- 1 was elucidated by antibodies against TNF receptor (TNFR) 1 or TNFR2 or inhibitors of nuclear factor-kappaB (NF$\mathrm{KB}$ ), phosphatidylinositol 3-kinase (PI3K) or Akt. In vivo studies were done on male $\mathrm{db} / \mathrm{m}$ and type 2 diabetic $d b / d b$ mice. Levels of TNF- $\alpha$ and MCP-1 were measured by RT-qPCR and ELISA in the urine, kidney and plasma of the two cohorts and correlated with albuminuria. Results: Podocytes treated with TNF- $\alpha$ showed a robust increase ( 900\%) in the secretion of MCP-1, induced in a dose- and time-dependent manner. Signaling of MCP-1 expression occurred through TNFR2, which was inducible by TNF- $\alpha$ ligand, but did not depend on TNFR1. TNF- $\alpha$ then proceeded via the NF-KB and the PI3K/Akt systems, based on the effectiveness of the
\end{abstract}

C.H. Chung, J. Fan and E.Y. Lee contributed equally to this work. 
inhibitors of those pathways. For in vivo relevance to diabetic kidney disease, TNF- $\alpha$ and MCP1 levels were found to be elevated in the urine of $d b / d b$ mice but not in the plasma. Conclusion: TNF- $\alpha$ potently stimulates podocytes to produce MCP-1, utilizing the TNFR2 receptor and the NF-KB and PI3K/Akt pathways. Both TNF- $\alpha$ and MCP-1 levels were increased in the urine of diabetic $d b / d b$ mice, correlating with the severity of diabetic albuminuria.

(C) 2015 S. Karger AG, Basel

\section{Introduction}

Tumor necrosis factor (TNF)- $\alpha$, a potent cytokine associated with inflammatory response, is believed to play a major role in many kidney diseases, including diabetic nephropathy. TNF- $\alpha$ mRNA and protein expressions are known to be elevated in the kidney of streptozotocin (STZ)-induced diabetic rats [1-3], and TNF- $\alpha$ protein is excreted in increased amounts in the urine of diabetic subjects [4]. When TNF- $\alpha$ signaling is prevented by a chimeric monoclonal anti-TNF- $\alpha$ antibody in the STZ-diabetic rat, albuminuria and urinary TNF- $\alpha$ excretion are both significantly reduced [5].

In the diabetic kidney, various inflammatory cells and resident kidney cells such as renal tubular [6, 7], mesangial [6], glomerular endothelial, and dendritic cells [8] produce TNF- $\alpha$. Podocytes may also generate TNF- $\alpha$ [9], and high glucose has been shown to increase podocyte TNF- $\alpha$ mRNA expression after 14 days [10]. The locally secreted TNF- $\alpha$ could have potent effects upon the kidney, such as the recruitment of polymorphonuclear neutrophils and monocytes, the local generation of reactive oxygen species and an increase in the glomerular permeability to albumin $[11,12]$. The multitude of biological activities of TNF- $\alpha$ could converge to inflict damage to the kidney in diabetes, but the precise mechanisms remain to be elucidated.

One of the potential links between TNF- $\alpha$ and the manifestations of diabetic nephropathy is the chemokine monocyte chemoattractant protein-1 (MCP-1). TNF- $\alpha$ is known to induce MCP-1 in human mesangial cells [13]; and MCP-1, being upregulated in the diabetic kidney, promotes the accumulation of macrophages, the progression of renal fibrosis, the exacerbation of diabetic albuminuria, and a decrement in kidney clearance function [14-16]. With regard to podocytes, however, the effect of TNF- $\alpha$ upon MCP-1 production has scarcely been studied. Furthermore, our discovery of an MCP-1/CCR2 loop that increases podocyte motility and permeability to albumin gives additional impetus to investigate the relationship between TNF- $\alpha$ and MCP-1 [17]. Insofar as diabetic nephropathy may be attributable to TNF- $\alpha[5,18]$, it is worthwhile to study TNF- $\alpha$-induced podocytopathy. Podocytes are subject to the increased TNF- $\alpha$ levels in the diabetic state and are competent to respond to TNF- $\alpha$, with conditionally immortalized podocytes expressing both TNF receptors (TNFR) 1 and 2 [9].

\section{Methods}

Cell Culture

Conditionally immortalized mouse podocytes (a gift of Dr. Peter Mundel, Harvard University, Boston, Mass., USA) were cultured as previously described [19, 20]. Differentiated podocytes were synchronized into quiescence by growing cells in serum-free medium for $24 \mathrm{~h}$ before the experiment. To examine the effects of TNF- $\alpha$ on MCP-1 generation, the cells were treated with recombinant mouse TNF- $\alpha$ (R\&D Systems, Minneapolis, Minn., USA) at the dose and time indicated in each Results section. To neutralize the TNFRs, hamster anti-TNFR1 IgG (R\&D Systems) and hamster anti-TNFR2 IgG (BD Biosciences, San Jose, Calif., USA) antibodies 
were used. Control antibody was hamster IgG (BD Biosciences). To demonstrate the pathways involved in TNF- $\alpha$-induced MCP-1 production, the following specific inhibitors were added concurrently with the TNF- $\alpha$ treatment: nuclear factor kappaB (NF- $\kappa \mathrm{B}$ ) activation inhibitor (BAY 11-7082; Enzo Life Sciences, Farmingdale, N.Y., USA), phosphatidylinositol 3-kinase (PI3K) inhibitor (LY294002; EMD, San Diego, Calif., USA) or Akt inhibitor IV (EMD). The experiments were also done in high-glucose media ( 450 or $540 \mathrm{mg} / \mathrm{dl}$ dextrose) for $24 \mathrm{~h}$ or with advanced glycation endproduct-bovine serum albumin (AGE-BSA; $50 \mu \mathrm{g} / \mathrm{ml}$; Calbiochem, Billerica, Mass., USA) for $48 \mathrm{~h}$ to mimic specific metabolic features of diabetes.

\section{Experimental Animals}

All protocols using rodents were approved by the Institutional Animal Care and Use Committee of Northwestern University and were in compliance with the NIH Guide for the Care and Use of Laboratory Animals. Male diabetic $d b / d b$ mice (C57BLKS/J-Lepr ${ }^{d b} /$ Lepr $^{d b}$ ) and male nondiabetic $d b / m$ mice (C57BLKS/J-Lepr ${ }^{d b} /+$ ) were purchased at 6 to 7 weeks of age from Jackson Laboratory (Bar Harbor, Me., USA). By 8 weeks of age, all $d b / d b$ mice were hyperglycemic. The animals were provided with food and water ad libitum. The experiments were continued for 8 weeks, at which time the mice underwent a final 18-hour urine collection. Blood was obtained from the retro-orbital sinus during terminal anesthesia with isoflurane. Euthanasia was achieved by isoflurane and cervical dislocation. Urinary albumin concentrations were determined by the Albuwell $\mathrm{M}$ kit, and urinary creatinine was assayed by the Creatinine Companion kit (both kits from Exocell, Philadelphia, Pa., USA).

\section{Processing Kidneys into Protein Lysates}

Processing was done as previously reported by us [21, 22]. In brief, after being flushed with phosphate-buffered saline injected into the aorta, the mouse kidney was removed and mechanically homogenized in RIPA lysis buffer, supplemented with protease inhibitors and sodium orthovanadate. The preparation was then centrifuged at $14,000 \mathrm{~g}$, and the supernatant was collected as the kidney protein lysate. Its total protein concentration was measured by the Lowry assay (Bio-Rad, Hercules, Calif., USA). Renal levels of TNF- $\alpha$ and MCP-1 were measured by enzyme-linked immunosorbent assay (ELISA), as described below.

\section{Measurement of TNF- $\alpha$}

The TNF- $\alpha$ concentration in murine kidney lysate, urine or plasma was measured using a commercial quantitative sandwich ELISA (Pharmingen; BD Biosciences) that was specific for mouse TNF- $\alpha$ and sensitive down to $5 \mathrm{pg} / \mathrm{ml}$. The renal TNF- $\alpha$ concentration was normalized to the total protein concentration of the kidney lysate, and the urinary TNF- $\alpha$ concentration was normalized to the urinary creatinine concentration.

\section{Measurement of MCP-1}

The MCP-1 concentration in podocyte medium, kidney protein lysate, mouse urine, or mouse plasma was measured using a commercial quantitative sandwich ELISA (R\&D Systems) that was specific for mouse MCP-1 and sensitive down to $2 \mathrm{pg} / \mathrm{ml}$. The podocyte or renal MCP-1 concentration was normalized to the total protein concentration of the respective lysate, and the urinary MCP- 1 concentration was normalized to the urinary creatinine concentration.

\section{Assay for Cytotoxicity}

The potential for cellular cytotoxicity caused by the inhibitors was evaluated by a WST-1 assay kit (Cayman Chemical, Ann Arbor, Mich., USA), which is based on the reduction of a tetrazolium salt WST-1 to soluble formazan by electron transport across the plasma mem- 
Chung et al.: Effects of Tumor Necrosis Factor- $\alpha$ on Podocyte Expression of Monocyte Chemoattractant Protein-1 and in Diabetic Nephropathy

brane of viable cells [23]. Differentiated podocytes, grown on a type I collagen-coated 96-well plate at a density of $10^{4}$ cells/well, were incubated in serum-free DMEM with the reagents for the times indicated in the Results section. After a subsequent 2-hour incubation with reconstituted WST-1, optical density was measured at $450 \mathrm{~nm}$. Alternatively, but still based on the reduction to formazan, the MTT assay was also used to assess cytotoxicity.

RT-PCR

Podocyte RNA was treated with DNase I to clear contaminating genomic DNA and reversetranscribed with 100 U Superscript II (Invitrogen, Carlsbad, Calif., USA), $0.5 \mu$ g gene-specific primer, $20 \mathrm{U}$ RNase inhibitor, and $1 \mathrm{mM}$ dNTPs. The RT reaction was carried out at $42^{\circ} \mathrm{C}$ for $50 \mathrm{~min}$, followed by inactivation at $70^{\circ} \mathrm{C}$ for $15 \mathrm{~min}$, after which RNase $\mathrm{H}$ was added and the mixture was incubated at $37^{\circ} \mathrm{C}$ for $30 \mathrm{~min}$. Subsequently, PCR was performed, with initial denaturation at $94^{\circ} \mathrm{C}$ for $1 \mathrm{~min}$, followed by 40 cycles of denaturation at $94^{\circ} \mathrm{C}$ for $15 \mathrm{~s}$, annealing at $60^{\circ} \mathrm{C}$ for $1 \mathrm{~min}$, and extension at $72^{\circ} \mathrm{C}$ for $30 \mathrm{~s}$, with a final extension at $72^{\circ} \mathrm{C}$ for 8 min. Primers for mouse TNFR1 were $5^{\prime}$-CAG TCT GCA GGG AGT GTG AA-3' (forward) and 5'-CAC GCA CTG GAA GTG TGT CT-3' (reverse) [24], with a predicted size of $197 \mathrm{bp}$. Primers for TNFR2 were $5^{\prime}$-TAC CAA GGG TGG CAT CTC TC-3' (forward) and $5^{\prime}$-TCC TGG GAT TTC TCA TCA GG-3' (reverse), with the predicted size of the RT-PCR product being $171 \mathrm{bp}$.

\section{Real-Time RT-qPCR}

Total RNA was isolated from cultured podocytes using TRIzol reagent (Life Technologies, Grand Island, N.Y., USA), and the purity of RNA was confirmed by an $A_{260 / 280}$ absorbance ratio $>1.8$. First-strand cDNA synthesis was carried out using the High-Capacity cDNA Reverse Transcription kit (Applied Biosystems, Grand Island, N.Y., USA) or ReverTra Ace (Toyobo, Osaka, Japan). Real-time RT-PCR was performed on a StepOnePlus PCR machine (Applied Biosystems) in a 10- $\mu$ l volume with TaqMan Gene Expression Master Mix (Applied Biosystems). Primers and FAM probes for mouse TNF- $\alpha$ (Mm00443258_m1), MCP-1 (Mm00441243_g1), TNFR1 (Mm00441875_m1), and TNFR2 (Mm00441889_m1) were purchased from ABI TaqMan Gene Expression Assay (Applied Biosystems, Life Technologies). PCR was run using standard conditions: initial $95^{\circ} \mathrm{C}$ for $10 \mathrm{~min}$ followed by 40 cycles of denaturation at $95^{\circ} \mathrm{C}$ for $15 \mathrm{~s}$ and then annealing and extension at $60^{\circ} \mathrm{C}$ for $60 \mathrm{~s}$. The relative expression of the gene of interest was measured by the $\Delta \Delta \mathrm{C}_{\mathrm{t}}$ method. To normalize the gene expression to a stable reference point not influenced by TNF- $\alpha$, the geNorm reference gene selection kit (PrimerDesign, Ltd., Southampton, UK) was used. Of the 12 candidate genes in that kit, mouse calnexin and phospholipase $\mathrm{A} 2$ were determined to work the best for housekeeping purposes, and all of the results were normalized to calnexin and phospholipase A2 expression. Additionally, for mouse TNF- $\alpha$, TNFR2 and MCP-1, the SYBR Green method was done using primers for (1) TNF- $\alpha$ : $5^{\prime}$-TCC CAG GTT CTC TTC AAG GGA-3' (forward) and 5'-GGT GAG GAG CAC GTA GTC GG-3' (reverse); (2) TNFR2: 5' -GTC GCG CTG GTC TTC GAA CTG-3' (forward) and 5'-GGT ATA CAT GCT TGC CTC ACA GTC-3' (reverse), and (3) MCP-1: 5'-CTG GAT CGG AAC CAA ATG AG-3' (forward) and 5'-CGG GTC AAC TTC ACA TTC AA-3' (reverse).

\section{Nuclear Fraction Isolation}

Mouse podocytes at $80 \%$ confluency were harvested from $10 \mathrm{~cm}$ culture dishes, washed twice with $4^{\circ} \mathrm{C}$ phosphate-buffered saline and subsequently centrifuged at $450 \mathrm{~g}$ for $5 \mathrm{~min}$. After removal of supernatant, cellular pellets were resuspended and incubated in isotonic lysis buffer $\left(10 \mathrm{~mm}\right.$ Tris $\mathrm{HCl}, \mathrm{pH} 7.5,2 \mathrm{mM} \mathrm{MgCl}_{2}, 3 \mathrm{mM} \mathrm{CaCl}_{2}, 0.3 \mathrm{M}$ sucrose, and protease inhibitor cocktail) for 15-20 min until obvious swelling of the cellular membranes was observed. The swollen cells were centrifuged at $11,000 \mathrm{~g}$ for $30 \mathrm{~s}$ to pellet the heavy nuclear fractions. After removal of supernatant, nuclear pellets were incubated for $30 \mathrm{~min}$ in an 
extraction buffer (20 mM HEPES, pH 7.9, $1.5 \mathrm{~mm} \mathrm{MgCl}_{2}, 0.42 \mathrm{M} \mathrm{NaCl}, 0.2$ EDTA, 25\% (v/v) glycerol, and protease inhibitor cocktail) at $4^{\circ} \mathrm{C}$ with gentle agitation. Solubilized nuclear proteins in this supernatant were collected after centrifugation at 20,000 $\mathrm{g}$ for $5 \mathrm{~min}$.

\section{Western Blotting}

The podocyte lysate was homogenized in RIPA lysis buffer and spun at 14,000 $\mathrm{g}$ to pellet the nuclei and large cellular fragments. The supernatant protein concentrations or the nuclear fraction protein concentrations were measured by the Lowry assay (Bio-Rad) and equalized with the addition of Laemmli buffer, before SDS-based electrophoresis through a 3-8\% gradient polyacrylamide gel (Invitrogen). Proteins were electrically transferred to a nitrocellulose membrane that was probed with the appropriate primary antibody: rabbit antiphospho-Akt (Ser473; Cell Signaling, Beverly, Mass., USA), rabbit anti-Akt (Cell Signaling) or mouse anti-RelA/p65 (R\&D Systems). After incubation with horseradish peroxidase-conjugated secondary antibody, anti-rabbit or anti-mouse IgG (both GE Healthcare, Piscataway, N.J., USA), the chemiluminescent reaction was developed with SuperSignal West Pico (Pierce, Rockford, Ill., USA).

\section{Immunostaining Kidney for TNFR2}

Frozen kidney sections from the male $d b / m$ and $d b / d b$ mice were air-dried on glass slides for $30 \mathrm{~min}$, fixed with $100 \%$ cold acetone for $10 \mathrm{~min}$, blocked with 1\% BSA for 45-60 min at $37^{\circ} \mathrm{C}$, and incubated with primary anti-TNFR2 rabbit polyclonal antibody (sc-7862; Santa Cruz Biotechnology, Dallas, Tex., USA) for $1 \mathrm{~h}$ at $37^{\circ} \mathrm{C}$. Then the slides were incubated with secondary antibody, Alexa Fluor 488-conjugated goat anti-rabbit IgG (H+L; A-11008; Life Technologies) for $1 \mathrm{~h}$ at room temperature. Nuclear staining was done with DAPI (4',6-diamidino-2-phenylindole dihydrochloride). Immunofluorescence images were captured with a laser-scanning confocal microscope (LSM 510 Meta; Carl Zeiss Microimaging) at $600 \times$ magnification and overlaid onto the DAPI images.

\section{Statistical Analyses}

Data are displayed as the mean \pm SEM for the number of independent experiments or animals indicated. Student's $t$ test was used to compare two groups. One-way analysis of variance followed by Bonferroni's posttest was used to compare multiple groups. A p value $<0.05$ was considered statistically significant.

\section{Results}

Dose-Response of the TNF- $\alpha$ Effect on Podocyte MCP-1 Production

Podocytes were exposed to exogenous recombinant mouse TNF- $\alpha$ in doses of 1,10 and $100 \mathrm{ng} / \mathrm{ml}$ for $24 \mathrm{~h}$. Already $1 \mathrm{ng} / \mathrm{ml} \mathrm{TNF}-\alpha$ increased MCP-1 secretion into the culture media of the podocytes by 8.7-fold versus control (fig. $1 \mathrm{a}$ ). $10 \mathrm{ng} / \mathrm{ml}$ TNF- $\alpha$ stimulated MCP-1 secretion even more (12.4-fold vs. control, fig. 1a). The effect seemed to plateau at $10 \mathrm{ng} / \mathrm{ml}$; $100 \mathrm{ng} / \mathrm{ml}$ TNF did not increase MCP-1 secretion any further.

As is visible in figure 10, the circulating plasma level of TNF- $\alpha$ in the diabetic $d b / d b$ mouse is about $20 \mathrm{pg} / \mathrm{ml}$. To test a more 'physiological' concentration of TNF- $\alpha$ on the in vitro podocyte, we also included TNF- $\alpha$ doses below the $10 \mathrm{ng} / \mathrm{ml}$ that is otherwise used throughout. Besides the $1 \mathrm{ng} / \mathrm{ml}$ used above, the doses ranged from $0.020 \mathrm{ng} / \mathrm{ml} \mathrm{(20} \mathrm{pg/ml)} \mathrm{to} 0.100 \mathrm{ng} /$ $\mathrm{ml}(100 \mathrm{pg} / \mathrm{ml})$. Both of these TNF- $\alpha$ concentrations were able to elicit a significantly increased production of MCP-1 at $24 \mathrm{~h}$ (fig. 1b). The graph shows a graded dose-response curve for sub-10 ng/ml TNF- $\alpha$ doses. 


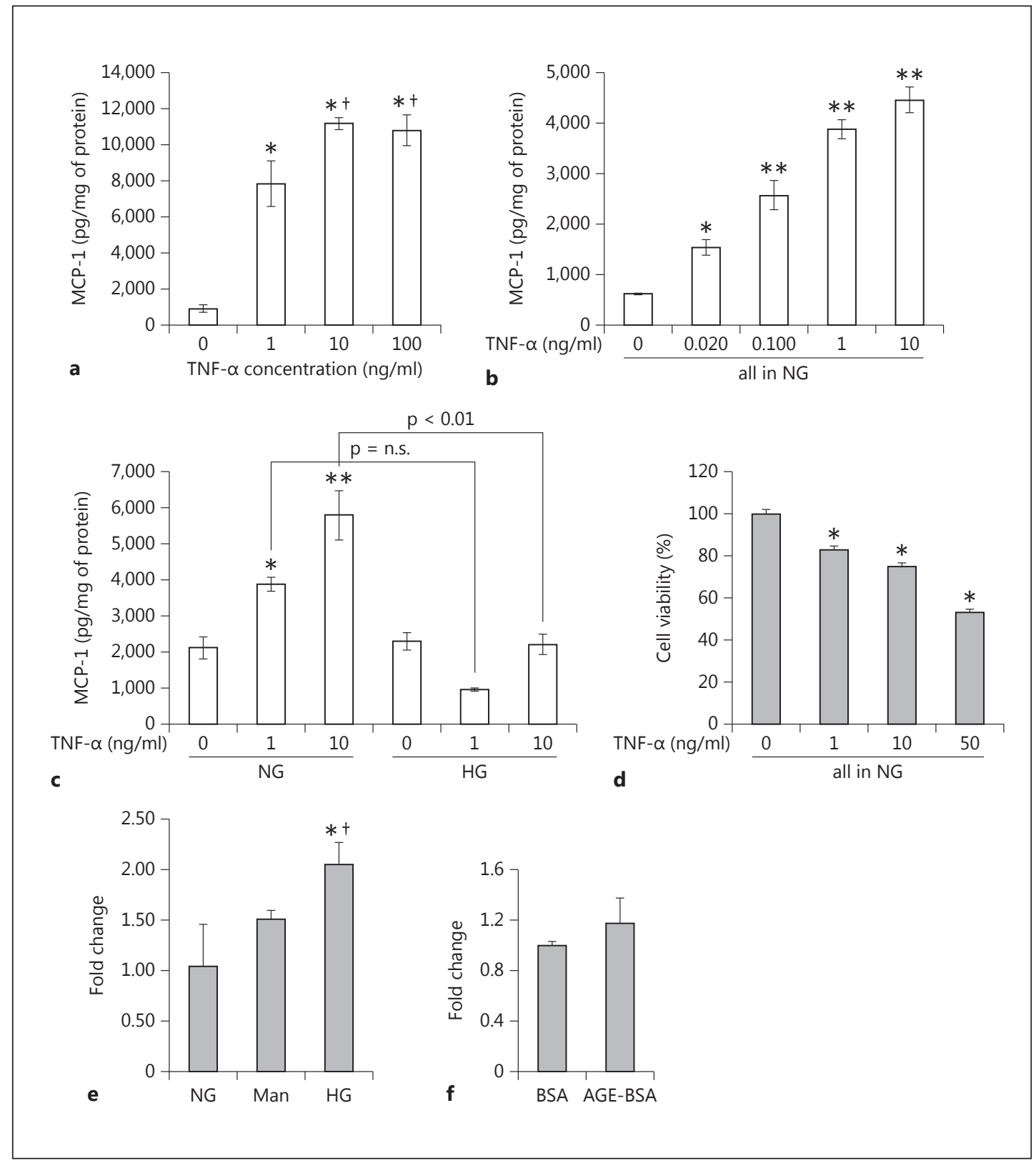

Fig. 1. TNF- $\alpha$ stimulates MCP-1 production and secretion in cultured podocytes. Differentiated mouse podocytes were treated with incremental doses of recombinant mouse TNF- $\alpha$ for $24 \mathrm{~h}$. a Compared with control, TNF- $\alpha$ markedly increased MCP-1 concentrations, measured by ELISA, in the conditioned media $(n=4)$. $* \mathrm{p}<0.005$ vs. control, ${ }^{\dagger} \mathrm{p}<0.05$ vs. $1 \mathrm{ng} / \mathrm{ml} \mathrm{TNF}-\alpha$. b More physiological concentrations of circulating TNF- $\alpha$ that are found in diabetes were also tested. At 20 and $100 \mathrm{pg} / \mathrm{ml}$, the podocyte production of MCP-1 was significantly increased, in a graded dose-response manner with 1 and $10 \mathrm{ng} / \mathrm{ml} \mathrm{TNF-} \alpha(\mathrm{n}=3) .{ }^{*} \mathrm{p}<0.05$ and ** $\mathrm{p}<0.01$ vs. control $(0 \mathrm{ng} / \mathrm{ml}$ TNF- $\alpha$ ). c The effect of high glucose (HG) medium for $24 \mathrm{~h}$ was tested. Dextrose at $450 \mathrm{mg} / \mathrm{dl}$ seemed to inhibit the ability of TNF- $\alpha$ to induce podocyte MCP-1, especially at the $10 \mathrm{ng} /$ $\mathrm{ml}$ dose, with a $\mathrm{p}<0.01$ for the comparison between normal glucose (NG) and HG (n = 3). ${ }^{*} \mathrm{p}<0.05$ and ** $\mathrm{p}<0.01$ vs. $0 \mathrm{ng} / \mathrm{ml}$ TNF- $\alpha$ in NG. d Testing cytotoxicity, an MTT assay showed that escalating doses of TNF- $\alpha$ from 0 (control) to $50 \mathrm{ng} / \mathrm{ml}$ progressively decreased podocyte viability $(\mathrm{n}=6){ }^{*} \mathrm{p}<0.01 \mathrm{vs.} 0 \mathrm{ng} / \mathrm{ml}$ TNF- $\alpha$ in NG. e Dextrose at $540 \mathrm{mg} / \mathrm{dl}$ for $24 \mathrm{~h}$ stimulated TNF gene expression by about 2-fold compared with control (100 mg/dl dextrose) and osmotic control (30 mM mannitol) (n=2). ${ }^{*} \mathrm{p}<0.05 \mathrm{vs.} \mathrm{NG.}{ }^{\dagger} \mathrm{p}<0.05$ vs. mannitol. f AGE-BSA at $50 \mu \mathrm{g} / \mathrm{ml}$ did not significantly affect TNF- $\alpha$ mRNA expression compared to control $\operatorname{BSA}(\mathrm{n}=2)$. 
Chung et al.: Effects of Tumor Necrosis Factor- $\alpha$ on Podocyte Expression of Monocyte Chemoattractant Protein-1 and in Diabetic Nephropathy

Fig. 2. Time course of TNF- $\alpha$ stimulation of MCP-1 mRNA expression in cultured podocytes. Differentiated mouse podocytes were treated with $10 \mathrm{ng} / \mathrm{ml}$ recombinant mouse TNF- $\alpha$ for the indicated periods of time up to $48 \mathrm{~h}$. TNF- $\alpha$ potently increased MCP-1 gene expression, assayed by RTqPCR, in treated podocytes at $24 \mathrm{~h}$ (13.3-fold) and $48 \mathrm{~h}$ (11-fold). $* * * \mathrm{p}<0.005$ vs. control $(\mathrm{n}=3)$.

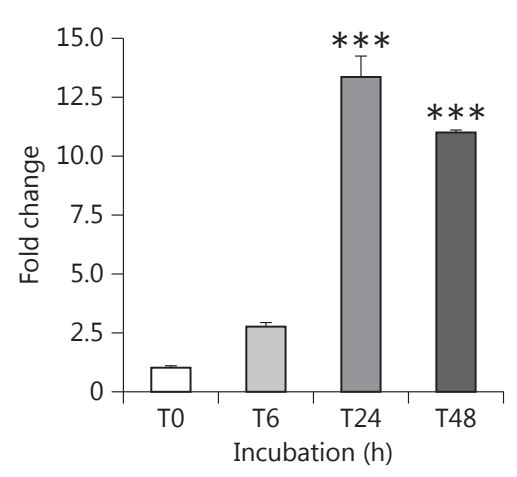

We then tested if high glucose might modulate the stimulatory effect of TNF- $\alpha$ on podocyte MCP-1 production. TNF- $\alpha$ at 1 and $10 \mathrm{ng} / \mathrm{ml}$ induces MCP- 1 in normal glucose medium, as expected (fig. 1c). But in the presence of high glucose medium ( $450 \mathrm{mg} / \mathrm{dl}$ dextrose), the TNF- $\alpha$ doses do not seem to be able to stimulate MCP-1 production further at $24 \mathrm{~h}$ (fig. $1 \mathrm{c}$ ). A 14-day treatment with high glucose [10] was not compatible with the time course of TNF- $\alpha$ effect. Finally, an MTT assay for cytotoxicity showed that TNF- $\alpha$ reduced podocyte viability in a dose-response manner up to $50 \mathrm{ng} / \mathrm{ml}$ (fig. 1d).

\section{Effects of High Glucose and AGE on TNF- $\alpha$}

High glucose may not further stimulate MCP-1 secretion beyond the robust effect of TNF- $\alpha$, but high glucose did increase the expression of TNF- $\alpha$. When treated for $24 \mathrm{~h}$ with 540 $\mathrm{mg} / \mathrm{dl}$ dextrose, the cultured podocytes demonstrated an about 2-fold increase in TNF- $\alpha$ mRNA expression. However, a significant increase in TNF- $\alpha$ mRNA was not seen with an osmotic control (mannitol; fig. 1e). In contrast to high glucose, $50 \mu \mathrm{g} / \mathrm{ml}$ of an advanced glycation endproduct for $48 \mathrm{~h}$ did not increase the expression of TNF- $\alpha$ compared to a nonglycated protein control (AGE-BSA vs. BSA; fig. 1f).

Time Course of the TNF- $\alpha$ Effect on Podocyte MCP-1

With the dose of TNF- $\alpha$ fixed at $10 \mathrm{ng} / \mathrm{ml}$, the stimulation of MCP- 1 secretion by mouse podocytes was evident in as short as $6 \mathrm{~h}$ (16.3-fold). Additional exposure time to TNF- $\alpha$ further increased the secretion of MCP-1 protein, and the effect of TNF- $\alpha$ persisted over a 48-h incubation (10.1-fold). The gradual MCP-1 increase under control conditions reflects MCP-1 accumulating in the medium over time. However, the rate of MCP-1 accumulation due to the TNF- $\alpha$-treated podocytes far exceeded that from the control podocytes. Concordant with the protein production, the TNF- $\alpha$-induced gene expression of MCP-1, seen by RT-qPCR, increased exuberantly with time. The mRNA level peaked at around 13-fold at $24 \mathrm{~h}$ before dipping somewhat to $\sim 11$-fold at $48 \mathrm{~h}$ (fig. 2).

\section{Podocytes Express Both TNFRs}

Differentiated cultured mouse podocytes showed mRNA expression by RT-PCR of both TNFR1 (TNFRSF1A, accession No. NM_011609) and TNFR2 (TNFRSF1B, accession No. NM_011610; fig. 3). The bands are of the expected sizes (197 and $171 \mathrm{bp}$, respectively) and do not arise from genomic DNA contamination, as the primer sets each cross an exon-intron junction. As negative controls, RNA treated with DNase but not reverse-transcribed did not show any PCR band (fig. 3). 
Chung et al.: Effects of Tumor Necrosis Factor- $\alpha$ on Podocyte Expression of Monocyte Chemoattractant Protein-1 and in Diabetic Nephropathy

Fig. 3. RT-PCR demonstrating gene expression of the TNFRs in podocytes. Total mRNA in the podocyte was DNase I-treated and then reverse-transcribed using oligo-dT. PCR was performed using exon-junction spanning primer pairs that are specific for the murine TNFR1 and TNFR2. On the agarose gel, PCR product bands are positive for both TNFR1 and TNFR2, with predicted amplicon sizes of 197 and $171 \mathrm{bp}$, respectively. As a negative control, the RT reaction was omitted, and the PCR bands no longer appear. 1 = TNFR1, DNase I-treated, not reverse-transcribed; 2 = TNFR1 primers; 3 = TNFR2 primers; 4 = TNFR2, DNase I-treated, not reverse-transcribed; $\mathrm{M}=$ marker in $\mathrm{bp}$.

Fig. 4. TNFR2 mediates TNF- $\alpha-$ induced MCP-1 in podocytes. Compared to a species-matched control antibody, a neutralizing anti-TNFR1 antibody had no significant effect on the induction of MCP- 1 by $10 \mathrm{ng} / \mathrm{ml}$ TNF- $\alpha$ for $6 \mathrm{~h}$. In contrast, a neutralizing antiTNFR2 antibody completely prevented the stimulation of MCP-1 protein production. Combination therapy with both neutralizing antibodies had no further effect versus anti-TNFR2 alone. $p$ values are as shown for the relevant comparisons $(n=3)$.

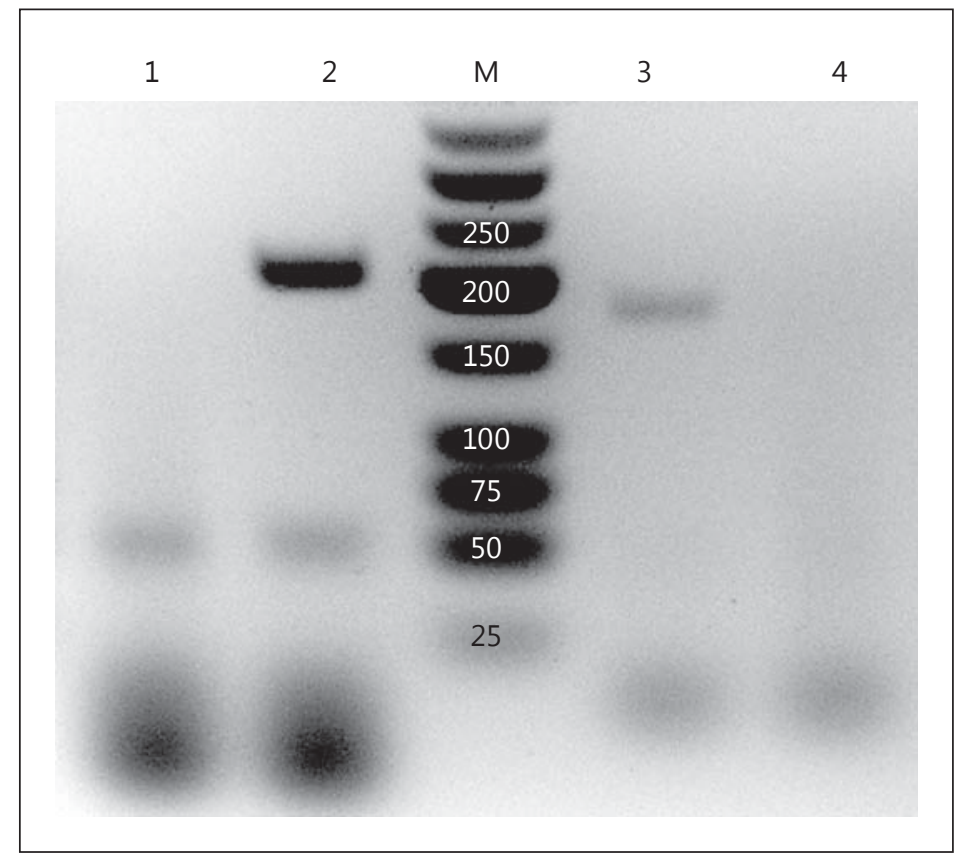

\section{TNFR2 Is the Primary TNFR in Podocytes}

To establish which TNFR(s) was mediating the effect of exogenous TNF- $\alpha$ on MCP-1 production in podocytes, specific neutralizing antibodies against either TNFR1 $(60 \mu \mathrm{g} / \mathrm{ml})$ or TNFR2 $(20 \mu \mathrm{g} / \mathrm{ml})$ or both or else a species- and isotype-matched control IgG was added. 10 $\mathrm{ng} / \mathrm{ml} \mathrm{TNF}-\alpha$ was added for $6 \mathrm{~h}$. A second set of podocytes undergoing the same experiment showed no effect of the antibodies on cell viability by WST-1 assay. In the presence of control IgG, $10 \mathrm{ng} / \mathrm{ml}$ TNF- $\alpha$ increased the MCP-1 quantity in the medium (fig. 4). When neutralizing anti-TNFR1 antibody was used, no attenuation of MCP-1 secretion was seen. However, when neutralizing TNFR2 antibody was used, the increase in MCP-1 due to TNF- $\alpha$ was abrogated (fig. 4). The combination of both anti-TNFR1 and anti-TNFR2 had no additional effect compared to anti-TNFR2 alone (fig. 4). 
Fig. 5. TNFR2, but not TNFR1, gene expression is induced by TNF- $\alpha$. a Podocytes treated with $10 \mathrm{ng} / \mathrm{ml}$ TNF- $\alpha$ showed no change in TNFR1 mRNA levels by real-time RT-qPCR at either 24 or $48 \mathrm{~h}$ of treatment. b However, there was a significant increase in TNFR2 mRNA levels at both 24 and $48 \mathrm{~h}$ of treatment with TNF- $\alpha$. ${ }^{*} \mathrm{p}<0.01$ and $^{* *} \mathrm{p}<0.05$ vs. control at T0 (n=3). c, d Further investigating TNFR2, we found that high glucose (540 mg/dl; HG) for $24 \mathrm{~h}$ did not change the expression but that AGE-BSA $(50 \mu \mathrm{g} / \mathrm{ml})$ for $48 \mathrm{~h}$ did increase TNFR2 mRNA expression by more than 2 -fold $(n=2)$. * $p<0.05$ vs. BSA. e By immunohistological fluorescence (IF), the amount of TNFR2 protein localized in the glomerulus was increased in the $d b / d b$ vs. $d b / m$ mice. A representative photomicrograph is shown $(\times 600$ magnification).
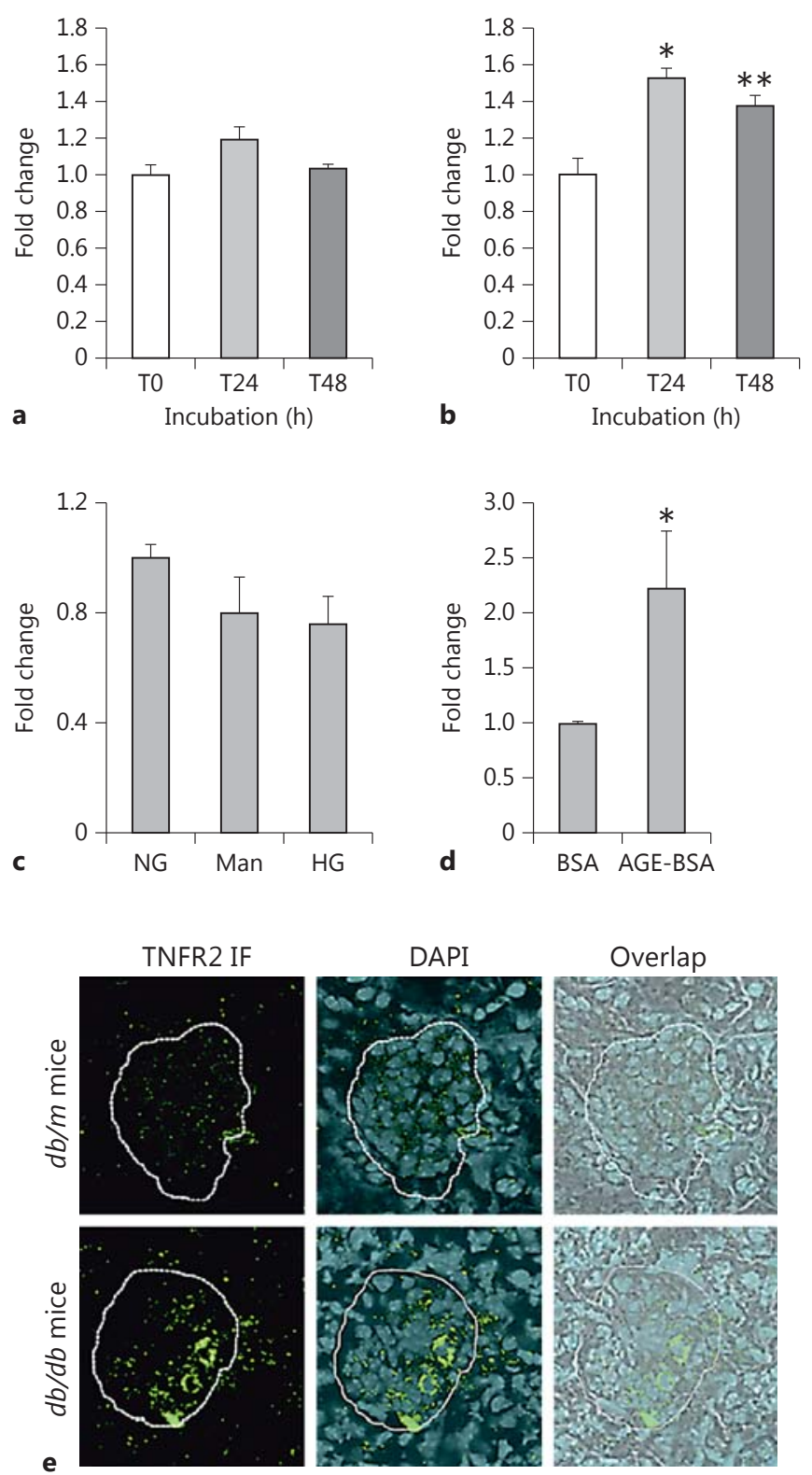

Overlap
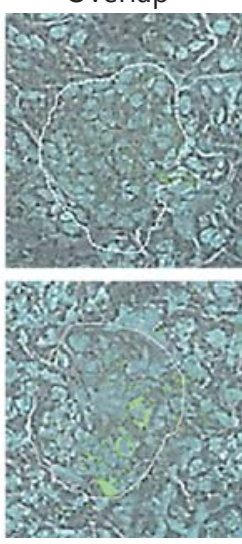

TNFR2 Expression in Podocytes Is Increased by TNF- $\alpha$

Cultured podocytes treated with $10 \mathrm{ng} / \mathrm{ml} \mathrm{TNF}-\alpha$ for 24 or $48 \mathrm{~h}$ were isolated for total RNA and quantified for mRNA encoding TNFR1 or TNFR2. The message for TNFR1 did not change significantly at either 24 or $48 \mathrm{~h}$ (fig. 5a). In contrast, the message for TNFR2 increased by $\sim 60 \%$ at $24 \mathrm{~h}$ and remained significantly increased by $\sim 40 \%$ at $48 \mathrm{~h}$ (fig. $5 \mathrm{~b}$ ), showing that TNFR2 gene expression in the podocyte is inducible by its ligand TNF.

TNFR2 Is Increased by AGE but Not by High Glucose

Podocytes treated for $24 \mathrm{~h}$ in $540 \mathrm{mg} / \mathrm{dl}$ dextrose did not show any significant change in the mRNA expression of TNFR2. Neither was the podocyte TNFR2 increased by $24 \mathrm{~h}$ of 
Chung et al.: Effects of Tumor Necrosis Factor- $\alpha$ on Podocyte Expression of Monocyte Chemoattractant Protein-1 and in Diabetic Nephropathy

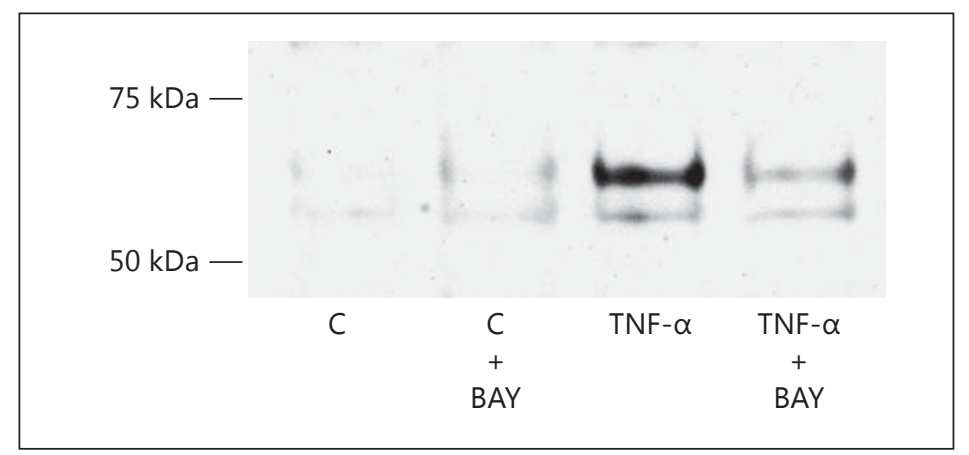

Fig. 6. TNF- $\alpha$-induced increase in the nuclear localization of the p65 subunit of NF- $\kappa B$ (RelA) is inhibited by BAY 11-7082 (BAY). The representative Western blot performed on podocyte nuclear extracts shows that the p65 band, positioned between the 50- and 75-kDa molecular weight markers, only became prominent when treatment with $10 \mathrm{ng} / \mathrm{ml}$ TNF- $\alpha$ occurred. When the podocytes were pretreated with BAY 11-7082 to inhibit NF- $\kappa B$ signaling, TNF- $\alpha$ was markedly hampered from increasing the translocation of p65 into the nucleus, seen in the diminished Western band intensity of TNF- $\alpha+$ BAY vs. TNF- $\alpha$ alone. C $=$ Control.

exposure to an osmotic control (mannitol; fig. 5c). On the other hand, TNFR2 gene expression was markedly stimulated by $50 \mu \mathrm{g} / \mathrm{ml}$ AGE-BSA versus control BSA for $48 \mathrm{~h}$ (fig. $5 \mathrm{~d}$ ).

TNFR2 Protein Is Increased in the Glomerulus of the $\mathrm{db} / \mathrm{db}$ Mouse

Frozen kidney sections were immunostained for TNFR2. The $d b / m$ controls showed almost no green fluorescent signal, indicating a dearth of TNFR2 protein in the glomerulus (fig. 5e). On the contrary, the $d b / d b$ mice exhibited noticeably increased amounts of TNFR2 fluorescent signal in the glomerulus (fig. 5e). It remains to be determined which glomerular cell types are expressing more TNFR2 in the diabetic state.

\section{$N F-\kappa B$ Is Involved in TNF- $\alpha$-Stimulated MCP-1}

Targeting of the NF- $\kappa B$ transcription factor was achieved with BAY 11-7082 that blocks the TNF- $\alpha$-induced phosphorylation of inhibitory $\kappa B-\alpha$. When not phosphorylated, inhibitory $\kappa B-\alpha$ continues to sequester NF- $\kappa B$ in the cytoplasm. Podocytes were pretreated with $2 \mu \mathrm{M}$ BAY 11-7082 for $1 \mathrm{~h}$ and then treated with $10 \mathrm{ng} / \mathrm{ml}$ TNF- $\alpha$ for $12 \mathrm{~h}$. No cytotoxicity was seen due to BAY 11-7082 by WST-1 uptake in a parallel set of podocytes. The efficacy of BAY 11-7082 in podocytes was established by assaying the translocation of the p65 subunit (RelA) of NF- $\kappa B$ into the nucleus. At baseline, the Western blot band for the p 65 protein in the nucleus was barely detectable (fig. 6). Upon stimulation with $10 \mathrm{ng} / \mathrm{ml} \mathrm{TNF-} \alpha$, the levels of the NF- $\kappa B$ p65 subunit were visibly and markedly increased. Pretreatment with $2 \mu \mathrm{M}$ BAY 11-7082, however, prevented the increase of the nuclear p65 levels due to TNF- $\alpha$ (fig. 6). Assured of the efficacy of BAY 11-7082 on NF- $\mathrm{BB}$, we tested its ability to inhibit TNF- $\alpha$ from stimulating the podocyte production of MCP-1. As before, TNF- $\alpha$ caused MCP-1 to increase 10.5-fold (fig. 7). But $2 \mu \mathrm{M}$ BAY 11-7082 blunted the stimulatory effect of TNF- $\alpha$ on MCP-1 by $62 \%$ (fig. 7).

\section{PI3K Is Involved in TNF- $\alpha$-Stimulated MCP-1}

The PI3K pathway may mediate selected actions of TNF- $\alpha$, so its role was investigated in MCP-1 expression. Cultured podocytes were pretreated with or without increasing doses of LY294002 (an PI3K inhibitor) or $750 \mathrm{~nm}$ Akt inhibitor IV for $1 \mathrm{~h}$ and then treated with or without $10 \mathrm{ng} / \mathrm{ml} \mathrm{TNF-} \alpha$ for 6 or $48 \mathrm{~h}$. WST- 1 uptake assayed in parallel did not show cytotoxicity from LY294002 up to $50 \mu \mathrm{M}$. 
Chung et al.: Effects of Tumor Necrosis Factor- $\alpha$ on Podocyte Expression of Monocyte Chemoattractant Protein-1 and in Diabetic Nephropathy

Fig. 7. BAY 11-7082 (BAY) inhibits TNF- $\alpha$ from stimulating podocyte MCP-1 production. By blocking the activation of the NF- $\mathrm{KB}$ pathway, BAY 11-7082 significantly attenuated the stimulation of MCP-1 production by the podocyte in response to $10 \mathrm{ng} / \mathrm{ml}$ TNF- $\alpha$ for 12 h. BAY 11-7082 also seemed to attenuate podocyte MCP-1 production at baseline (in the absence of TNF- $\alpha$ ), but BAY 11-7082 alone vs. control was not statistically significant. $\mathrm{p}$ values are as shown $(n=4)$.

Fig. 8. The PI3K pathway is involved in TNF- $\alpha$ stimulation of MCP-1. a Representative Western blots of Phospho-Akt (pAkt) and Total Akt show that LY294002 was effective at inhibiting PI3K in cultured mouse podocytes. TNF- $\alpha$ at $10 \mathrm{ng} / \mathrm{ml}$ for $24 \mathrm{~h}$ increased the ratio of pAkt (Serine 473) to Akt, a measure of PI3K activation, by roughly 2 -fold. This was wholly prevented by concurrent treatment with $25 \mu \mathrm{M}$ LY294002, which also lowered the baseline pAkt/Akt ratio. b TNF- $\alpha$ at $10 \mathrm{ng} /$ $\mathrm{ml}$ for $48 \mathrm{~h}$ increased the podocyte production of MCP-1, as expected, but the effect was steadily attenuated by escalating doses of LY294002 (LY), with the inhibition of TNF- $\alpha$-induced MCP-1 becoming significant at $10 \mu \mathrm{M}$ LY294002. Inhibition was complete at LY294002 doses of $25 \mu \mathrm{M}$ and higher. ${ }^{*} \mathrm{p}<0.05$ vs. control. ${ }^{\dagger} \mathrm{p}<0.05$ vs. TNF- $\alpha(\mathrm{n}=4)$.
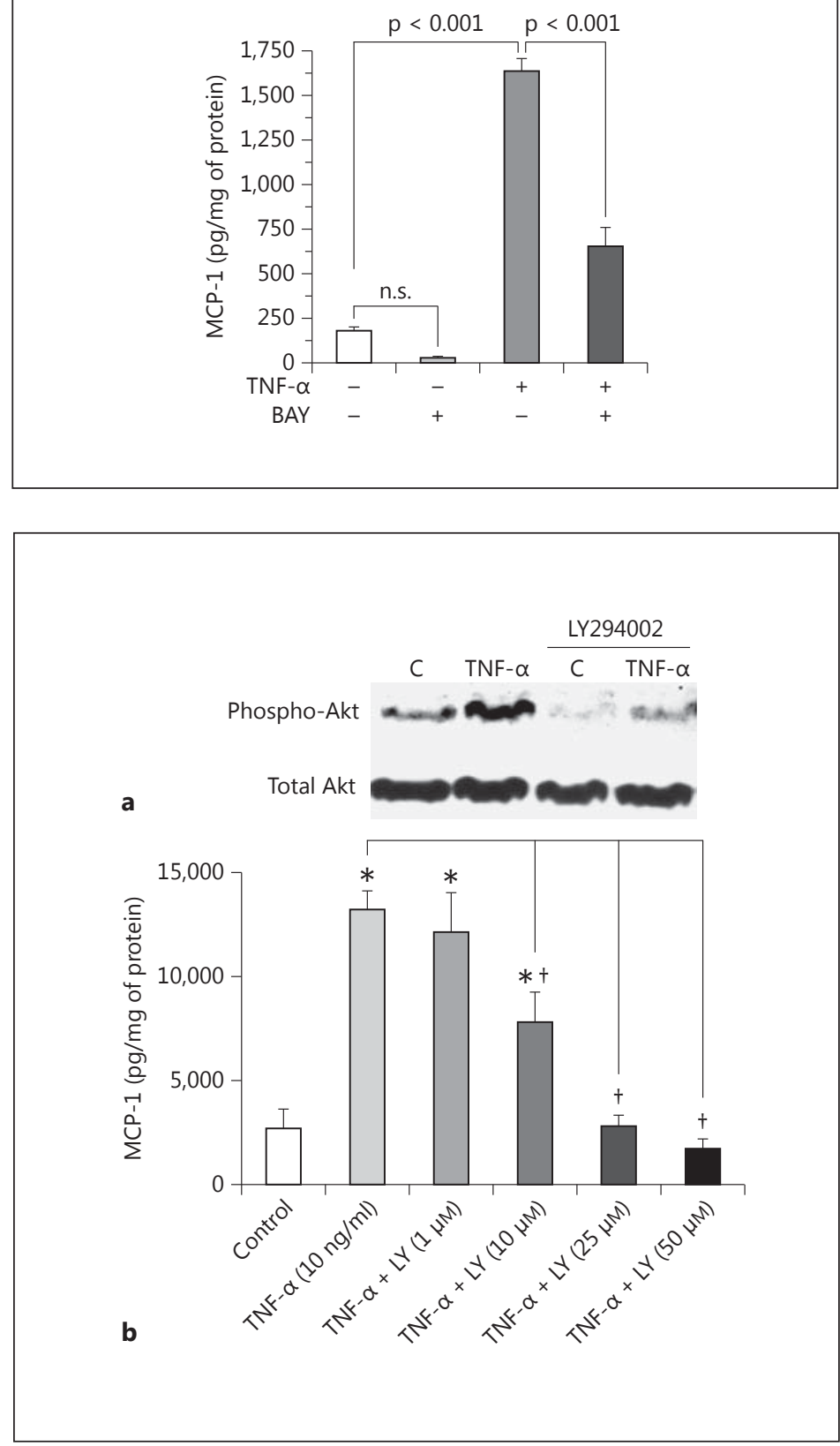

TNF- $\alpha$ increased PI3K activity, as revealed by the rise in phosphorylation of the PDK-1 substrate Akt (at serine residue 473), which is out of proportion to the amount of total Akt (fig. 8a). At $25 \mu \mathrm{M}$, the PI3K inhibitor LY294002 was able to reduce the phospho-Akt level at baseline, proving its efficacy in mouse podocytes. Further, LY294002 effectively abrogated Akt phosphorylation in response to TNF- $\alpha$ (fig. 8a).

When applied to podocytes treated with $10 \mathrm{ng} / \mathrm{ml} \mathrm{TNF-} \alpha$ for $48 \mathrm{~h}$, escalating doses of LY294002 progressively prevented TNF- $\alpha$ from stimulating MCP-1 production (fig. $8 \mathrm{~b}$ ). The threshold at which LY294002 started to significantly inhibit TNF- $\alpha$-induced MCP-1 lies around $10 \mu \mathrm{M}$. Inhibition is fairly complete at LY294002 doses of $25 \mu \mathrm{M}$ and higher (fig. 8b). 
Chung et al.: Effects of Tumor Necrosis Factor- $\alpha$ on Podocyte Expression of Monocyte Chemoattractant Protein-1 and in Diabetic Nephropathy

Fig. 9. Beyond PI3K, Akt is involved in TNF- $\alpha$ stimulation of MCP-1 in podocytes. The marked increase in MCP-1 production due to $10 \mathrm{ng} / \mathrm{ml} \mathrm{TNF}-\alpha$ for $6 \mathrm{~h}$ was significantly blunted by pretreatment with $750 \mathrm{nM}$ Akt inhibitor IV. In the absence of TNF- $\alpha$, Akt inhibitor IV also seemed to reduce the expression of MCP-1 at baseline, but Akt inhibitor IV vs. control was not statistically significant. $\mathrm{p}$ values are as shown $(\mathrm{n}=3)$.

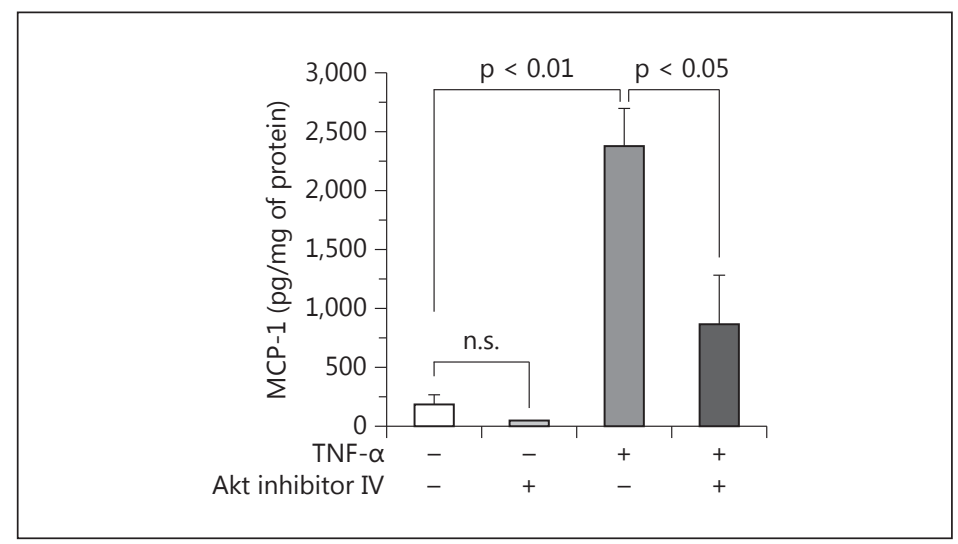

\section{Akt Also Participates in TNF- $\alpha$-Induced MCP-1}

Involvement of the PI3K pathway was found to extend downstream to Akt. When Akt was blocked by $750 \mathrm{~nm}$ Akt inhibitor IV, which did not adversely affect cell viability by WST-1 assay, a 6-hour TNF- $\alpha$ treatment of podocytes no longer stimulated MCP-1 expression to the same degree (fig. 9). The inhibition was significant (65\% decrease) and comparable to the effect of LY294002. Thus, TNF- $\alpha$-induced MCP-1 relies on at least two components of the PI3K pathway: PI3K and Akt.

TNF- $\alpha$ Concentrations in the Urine, Kidney and Blood of $d b / m$ and $d b / d b$ Mice

Ten diabetic $d b / d b$ mice were compared to 10 nondiabetic $d b / m$ age- and sex-matched littermates (all male). The urinary TNF- $\alpha$ level, adjusted for urinary creatinine, was significantly increased in the $d b / d b$ mice (2.5-fold) versus $d b / m$ mice (fig. 10). However, there were no significant differences in the concentrations of TNF- $\alpha$ protein in the kidney parenchyma or blood plasma (data not shown) between the $d b / d b$ and the $d b / m$ mice. Despite not being increased at the protein level, TNF- $\alpha$ mRNA expression was increased in the kidneys of the $d b / d b$ mice, assayed by real-time RT-qPCR (fig. 10).

MCP-1 Concentrations in the Urine, Kidney and Blood of $\mathrm{db} / \mathrm{m}$ and $\mathrm{db} / \mathrm{db}$ Mice

In the same animal cohorts, MCP-1 in the urine was also significantly increased in the diabetic $d b / d b$ mice compared with the control $d b / m$ mice (fig. 11). Again, there were no significant differences in the concentrations of MCP-1 protein in the kidney or plasma between the $d b / d b$ and the $d b / m$ mice. Similar to TNF- $\alpha$, MCP- 1 was not increased intrarenally at the protein level, but it was significantly increased at the mRNA level by real-time RT-qPCR in the kidneys of the $d b / d b$ mice (fig. 11).

\section{Albuminuria Is Increased in Diabetic $d b / d b$ Mice}

The urinary albumin-to-creatinine ratio was markedly increased in the diabetic $d b / d b$ mice versus the control $\mathrm{db} / \mathrm{m}$ mice $(636.26 \pm 95.16$ vs. $121.45 \pm 20.80 \mu \mathrm{g} / \mathrm{mg}$, respectively). Measured another way, the urinary albumin excretion was also increased when quantified as an absolute amount per day $(108.48 \pm 22.47 \mathrm{vs} .32 .15 \pm 6.03 \mu \mathrm{g} / \mathrm{day}$, respectively).

Correlations between Urinary TNF- $\alpha$, Urinary MCP-1 and Diabetic Albuminuria

The urinary TNF- $\alpha$ level was highly correlated with albuminuria $(\mathrm{r}=0.794$; fig. $12 \mathrm{a})$, and the urinary MCP-1 was also well correlated with albuminuria $(r=0.772$; fig. $12 \mathrm{~b})$. Compared 
Chung et al.: Effects of Tumor Necrosis Factor- $\alpha$ on Podocyte Expression of Monocyte Chemoattractant Protein-1 and in Diabetic Nephropathy

Fig. 10. TNF- $\alpha$ levels in the urine, kidney and plasma of $d b / d b$ diabetic mice. Urinary TNF- $\alpha$ was significantly increased in $d b / d b$ mice after 8 weeks of type 2 diabetes vs. control nondiabetic $\mathrm{db} / \mathrm{m}$ mice. $* \mathrm{p}<0.001$ vs. $d b / m$ mice. However, there were no significant differences between $d b / m$ and $d b / d b$ mice in the concentrations of TNF- $\alpha$ protein in the kidneys or plasma (data not shown). At the mRNA level, though, TNF- $\alpha$ was significantly increased in the kidneys of $d b / d b$ versus $d b / m$ mice. ** $\mathrm{p}<0.05$ vs. $d b / m$ kidneys ( $\mathrm{n}=$ 10 in both groups).

Fig. 11. MCP-1 levels in the urine, kidney and plasma of $d b / d b$ diabetic mice. Urinary MCP-1 was significantly increased in $d b / d b$ mice that were diabetic for $\sim 8$ weeks vs. $\mathrm{db} / \mathrm{m}$ mice that remained nondiabetic. ${ }^{*} \mathrm{p}<0.001$ vs. $d b / m$ mice. However, there were no significant differences between $\mathrm{db} / \mathrm{m}$ and $d b / d b$ mice in the concentrations of MCP-1 protein in the kidneys or plasma (data not shown). At the mRNA level, though, MCP-1 was significantly increased in the kidneys of $d b / d b$ vs. $d b / m$ mice. $* * \mathrm{p}<0.05$ vs. $d b / m$ kidneys $(\mathrm{n}=10$ in both groups).
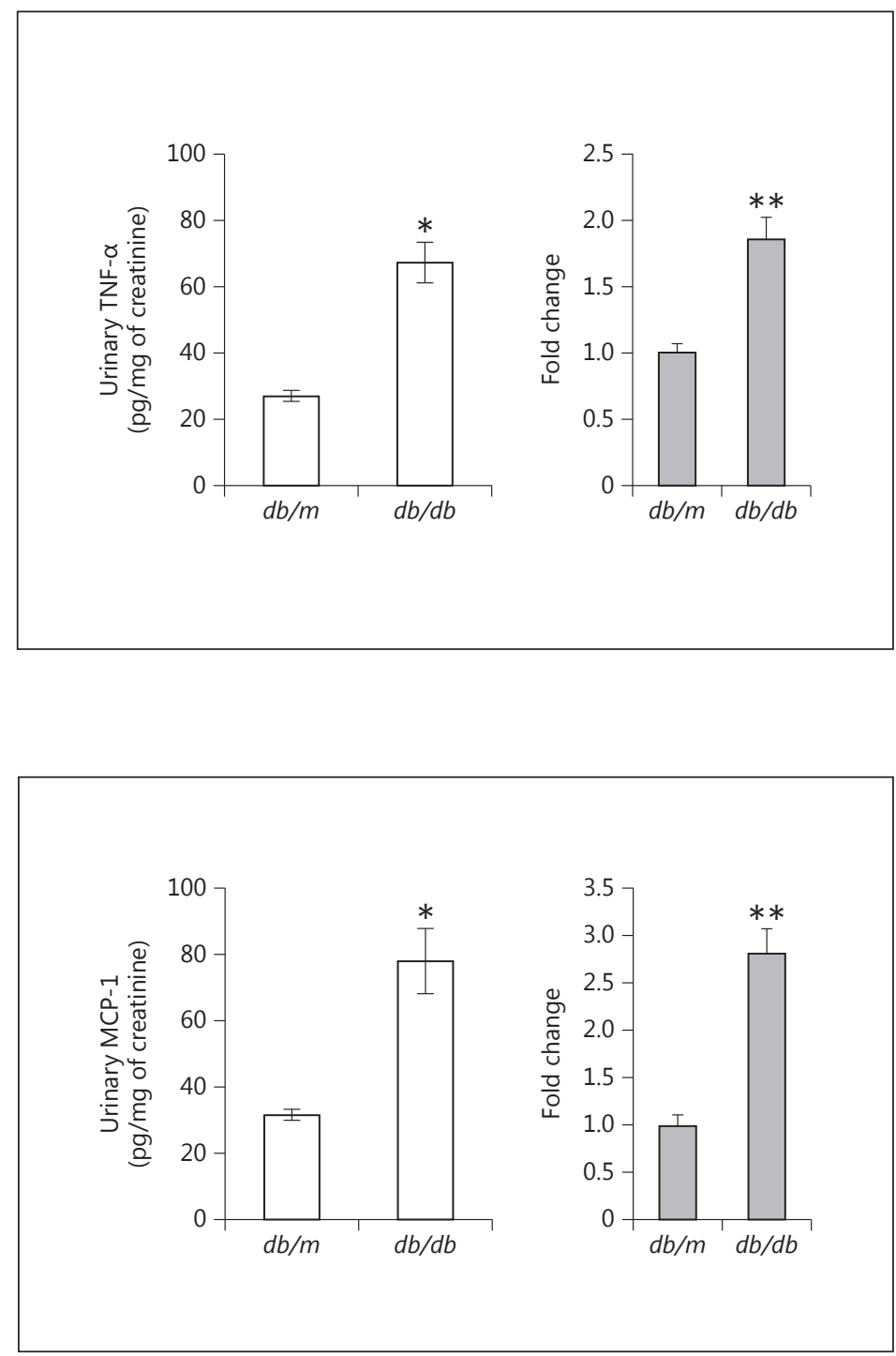

to each other, urinary TNF- $\alpha$ and urinary MCP-1 were significantly correlated $(r=0.611$; fig. 12c). On each graph, quadrants can be drawn that cleanly segregate the $d b / m$ from the $d b / d b$ mice.

\section{Discussion}

TNF- $\alpha$ stimulates the podocyte to generate copious levels of MCP- 1 , an effect that is dependent on TNFR2 followed by the NF- $\kappa B$ and PI3K pathways. Stimulation of MCP-1 by TNF- $\alpha$ is all the more impressive considering that TNF- $\alpha$ reduces podocyte viability, possibly due to an apoptotic effect [25]. Factors stimulating TNF- $\alpha$ in diabetes include high glucose, both in the short-term (fig. 1e) and in the long-term [10]. As we found, high glucose in the short-term may not foster TNF- $\alpha$-stimulated MCP-1 in podocytes, but other diabetic features may override the lack of effect. We have previously reported that transforming growth factor- $\beta$ stimulates podocyte MCP-1 [17]. Others have reported that angiotensin II induces 
Chung et al.: Effects of Tumor Necrosis Factor- $\alpha$ on Podocyte Expression of Monocyte

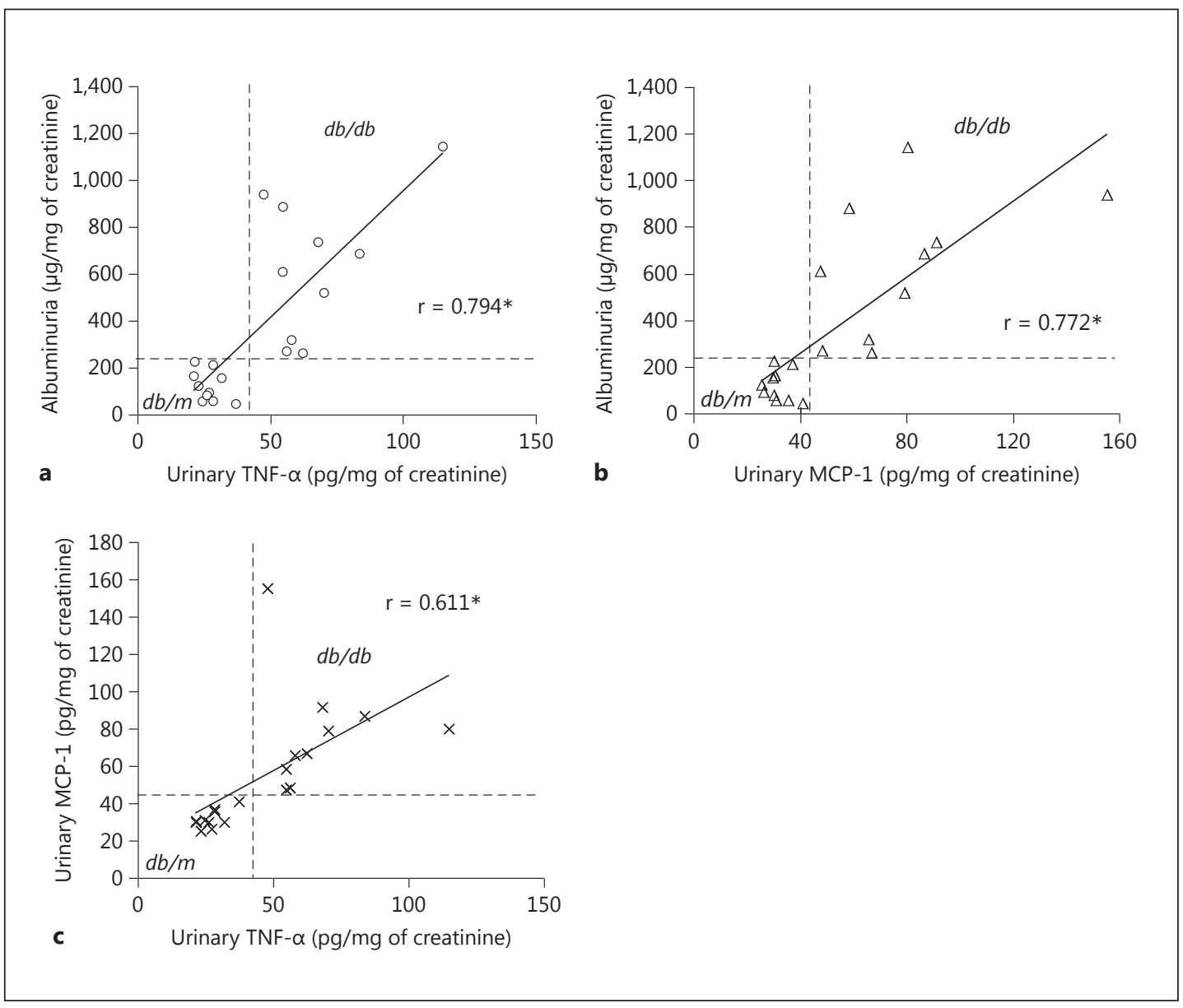

Fig. 12. Correlations between urinary TNF- $\alpha$, urinary MCP-1 and albuminuria in $d b / m$ and $d b / d b$ mice. a Urinary TNF- $\alpha$ was significantly correlated with albuminuria $(r=0.794)$. b Urinary MCP-1 was also well correlated with albuminuria $(\mathrm{r}=0.772)$. $\mathrm{c}$ In turn, both urinary TNF- $\alpha$ and urinary MCP-1 were correlated with each other $(\mathrm{r}=0.611)$. In each graph, the $d b / \mathrm{m}$ and $d b / d b$ datapoints cleanly segregate into opposite quadrants as drawn. ${ }^{*} \mathrm{p}<0.001$ for all comparisons ( $\mathrm{n}=10$ in both groups).

TNF- $\alpha$ in cultured podocytes [26]. Other testable candidates include amadori-glycated albumin, stretch, oxidative stressors, and AGEs. In our experiments, AGE-BSA did not increase TNF- $\alpha$ expression, but that does not preclude the efficacy of other AGE species. Ultimately, the relevance of increased TNF- $\alpha$ activity to diabetic nephropathy is borne out by the current in vivo studies in diabetic $d b / d b$ mice showing significant correlations between urinary TNF- $\alpha$ and MCP-1 levels and the degree of albuminuria. These results suggest that part of the pathogenesis of albuminuria in diabetic nephropathy might involve the way that TNF- $\alpha$ alters the biology of the podocyte and markedly stimulates the production of MCP-1.

The receptor on the mouse podocyte that is primarily responsible for mediating the effect of TNF- $\alpha$ on MCP-1 expression is TNFR2. In contrast, the other receptor in this TNFR family, TNFR1, does not appear to be involved. The predominance of TNFR2 in podocytes was first described in models of glomerulopathy and proliferative podocytopathy [27]. TNFR2, unlike TNFR1, is not basally expressed in most cells but rather is induced to be expressed in the kidney and specifically the podocyte by certain disease states $[9,28]$ and, in our data, by AGE-BSA. Our podocytes at baseline showed abundant TNFR1 message by RT-PCR but barely 
Chung et al.: Effects of Tumor Necrosis Factor- $\alpha$ on Podocyte Expression of Monocyte Chemoattractant Protein-1 and in Diabetic Nephropathy

detectable TNFR2 mRNA. TNFR2 expression became significantly elevated, however, when podocytes were treated with TNF- $\alpha$, a case in which the ligand upregulates its receptor. According to another study, however, TNF- $\alpha$ upregulates both TNFR1 and TNFR2 in podocytes [9]. In vivo, the glomeruli showed increased TNFR2 abundance by immunostaining in the $d b / d b$ mice. The $d b / m$ mice showed almost no TNFR2 signal at baseline, lending credence to the need for induction of its expression.

The TNF- $\alpha-T N F R 2$ axis is capable of activating NF- $\kappa B$ in podocytes and increasing MCP-1 protein by 2- to 3-fold, as reported by Bruggeman et al. [27]. However, an inhibitor of the NF- $\kappa B$ pathway was not employed, so our work nicely complements their study [27] and helps establish the role of NF- $\mathrm{BB}$ in stimulating MCP-1 expression. That NF- $\kappa \mathrm{B}$ regulates transcription of MCP-1 holds true in non-kidney cells as well [29]. Lastly, NF- $\kappa B$ signaling of MCP-1 is seen with stimuli other than TNF- $\alpha$, such as mechanical stretch in mesangial cells [30].

The relative importance of TNFR2 for podocytes is intriguing in the context of diabetic nephropathy. In type 1 diabetic patients followed at the Joslin Diabetes Center, those having the highest quartile of serum TNFR2 levels showed the highest risk for early renal decline [31]. High serum levels of TNFR1 were a close second. Conversely, in type 2 diabetic patients, those with the highest quartile of serum TNFR1 had the highest risk of end-stage renal disease after 12 years [32]. This time, high serum levels of TNFR2 were a close second. As for TNF- $\alpha$ itself, serum levels were only modestly associated with worsening diabetic kidney disease and not associated with end-stage renal disease [31, 32]. In our $d b / d b$ mice, plasma TNF- $\alpha$ levels did not correlate with being diabetic. Rather, TNF- $\alpha$ levels in the urine were elevated in the $d b / d b$ mice compared to the control $d b / m$ mice. Therapeutically, antagonizing TNF- $\alpha$ with etanercept, a soluble TNFR2 fusion protein, ameliorated albuminuria and early nephropathy in diabetic KK- $\mathrm{A}^{\mathrm{y}}$ mice [33]. Although the interaction between circulating, intrarenal and urinary markers of all TNF- $\alpha$ components remains to be clarified, together the reports suggest a powerful influence of the TNF- $\alpha$ system on the progression of diabetic nephropathy.

The discovery of PI3K as a signaling intermediary between TNF- $\alpha$ and MCP-1, at least in podocytes, points to an underrecognized mechanism of TNF- $\alpha$ signaling. The choices of signaling pathways that are available to TNF- $\alpha$ after binding to its cell surface receptors are manifold, but they include NF- $\kappa \mathrm{B}$, caspases and the mitogen-activated protein kinase family [34]. Only a few studies mention PI3K being interposed in the TNF- $\alpha$-to-MCP-1 pathway [3537 ], but none are in podocytes. Evidence is presented here that TNF- $\alpha$ stimulates PI3K activity in and of itself and that inhibition of PI3K is able to prevent TNF- $\alpha$-induced MCP-1. Further downstream of PI3K, Akt was also found to participate, strengthening the case for the involvement of PI3K/Akt signaling in the cascade from TNF- $\alpha$ to MCP-1.

TNF- $\alpha$ protein is excreted in increased amounts in the urine of diabetic subjects [4], a finding we were able to corroborate in the $d b / d b$ mice. Since podocytes are the first cells to interface with the urinary space, it is conceivable that podocytes are exposed to elevated levels of TNF- $\alpha$ in the diabetic state. Other TNF- $\alpha$ sources could come before the urinary space, with the mesangium shown to be capable of secreting TNF- $\alpha$ that impinges upon the podocyte [9]. Tubule cells also express and may secrete TNF- $\alpha$ into the urine [38]. Others reported that TNF- $\alpha$ mRNA and protein expressions are elevated in the kidney of STZ-induced diabetic rats [1-3]. One impact of high TNF- $\alpha$ may be to make the diabetic kidney more vulnerable to ischemic acute kidney injury [39]. In our $d b / d b$ mouse kidneys, there was a discrepancy between TNF- $\alpha$ mRNA (elevated) and TNF- $\alpha$ protein (no change). We rationalize that expression may be increased, but it is matched by an increased export of TNF- $\alpha$ protein out of the renal cell, which might explain the higher TNF- $\alpha$ protein content in the urine of diabetic $d b / d b$ mice. The increased intrarenal mRNA expression plus enhanced excretion into the urine could explain the similar discrepancy seen in $d b / d b$ mice with respect to MCP- 1 . 
Chung et al.: Effects of Tumor Necrosis Factor- $\alpha$ on Podocyte Expression of Monocyte

Chemoattractant Protein-1 and in Diabetic Nephropathy

The correlation of urinary TNF- $\alpha$ and urinary MCP-1 with the diabetic manifestation of albuminuria possibly represents more than just an association, as the urine MCP-1 level in type 2 diabetic humans also correlated inversely with the estimated glomerular filtration rate [40]. There are credible reasons to believe that TNF- $\alpha$ is causally connected to diabetic albuminuria and, further, that MCP-1 might bridge the two parameters. TNF- $\alpha$ increases nephrin and Neph3 mRNA expression, also via NF- $\kappa B$, in human podocytes [41], but TNF- $\alpha$ suppresses nephrin in mouse podocytes [42]. Although the reason for the species difference is unknown, the ability of TNF- $\alpha$ to dysregulate a critical slit diaphragm protein may provoke albuminuria and proteinuria, but this remains to be proven in diabetic nephropathy [43].

The case for a relationship between MCP-1 and diabetic albuminuria is also building. When MCP-1 knockout mice were made type 1 diabetic by STZ for up to 18 weeks, they were largely protected from developing nephropathy in the form of albuminuria, elevated plasma creatinine, hypertrophy, tubular injury, and renal fibrosis [44]. The damage wrought by MCP-1 in the wild type was believed to accrue from its ability to chemoattract and activate macrophages to infiltrate the diabetic kidney [45]. Similar macrophage accumulation was also shown to occur in the kidneys of $d b / d b$ mice [46].

Besides macrophages, the intrinsic kidney cells themselves could be affected by MCP-1, and relevant to the pathogenesis of albuminuria, MCP-1 is known to animate podocytes into increased motility and cause a podocyte monolayer to become more permeable to albumin $[17,47]$, which could have ramifications for the pathogenesis of albuminuria in vivo. Interestingly, MCP-1 does not need to come from outside the podocyte. MCP-1 derived from podocytes can increase motility in an autocrine/paracrine mode $[17,20]$, set into motion potentially by an increased urinary TNF- $\alpha$ level. Another way that MCP-1 might promote albuminuria is to suppress the podocyte expression of nephrin via a Rho-dependent mechanism [16] that is amenable to therapy with the PPAR- $\gamma$ agonist rosiglitazone [48]. Thus, the constellation of MCP-1 actions, both inflammatory and noninflammatory, might plausibly link TNF- $\alpha$ to albuminuria in diabetes.

In conclusion, urinary TNF- $\alpha$ excretion is increased in diabetes and is concordant with diabetic albuminuria, itself a powerful risk factor for the progression of chronic kidney disease. The effect of an increased TNF- $\alpha$ level upon podocytes is to induce robust MCP-1 production, which proceeds via TNFR2 to the NF- $\kappa B$ system and also the PI3K/Akt pathway. The overactivity of a podocyte-based TNF- $\alpha-$ TNFR2 $\rightarrow$ NF- $\kappa B / P I 3 K \rightarrow$ MCP-1 axis may play an important role in the pathophysiology of diabetic glomerulopathy.

\section{Acknowledgements}

The authors wish to thank Peter Mundel for the gift of the mouse podocyte line. This work was supported by Korean Research Foundation grant KRF-2007-013-E00022 (to C.H.C.), Basic Science Research Program through the National Research Foundation (NRF) of Korea funded by the Ministry of Education, Science and Technology (2012R1A1A2044121) (to E.Y.L.) and the National Institutes of Health R01 DK044513 grant and a Veterans Affairs Merit Review grant (to S.C.).

\section{Disclosure Statement}

The authors declare that there is no conflict of interest. 
Chung et al.: Effects of Tumor Necrosis Factor- $\alpha$ on Podocyte Expression of Monocyte Chemoattractant Protein-1 and in Diabetic Nephropathy

\section{References}

1 Nakamura T, Fukui M, Ebihara I, Osada S, Nagaoka I, Tomino Y, Koide H: mRNA expression of growth factors in glomeruli from diabetic rats. Diabetes 1993;42:450-456.

-2 Sugimoto H, Shikata K, Wada J, Horiuchi S, Makino H: Advanced glycation end products-cytokine-nitric oxide sequence pathway in the development of diabetic nephropathy: aminoguanidine ameliorates the overexpression of tumour necrosis factor-alpha and inducible nitric oxide synthase in diabetic rat glomeruli. Diabetologia 1999;42:878-886.

$\checkmark 3$ Mensah-Brown EP, Obineche EN, Galadari S, Chandranath E, Shahin A, Ahmed I, Patel SM, Adem A: Streptozotocin-induced diabetic nephropathy in rats: the role of inflammatory cytokines. Cytokine 2005;31:180-190.

4 Navarro JF, Mora C, Muros M, Garcia J: Urinary tumour necrosis factor-alpha excretion independently correlates with clinical markers of glomerular and tubulointerstitial injury in type 2 diabetic patients. Nephrol Dial Transplant 2006;21:3428-3434.

-5 Moriwaki Y, Inokuchi T, Yamamoto A, Ka T, Tsutsumi Z, Takahashi S, Yamamoto T: Effect of TNF-alpha inhibition on urinary albumin excretion in experimental diabetic rats. Acta Diabetol 2007;44:215-218.

-6 Chan LY, Leung JC, Tsang AW, Tang SC, Lai KN: Activation of tubular epithelial cells by mesangial-derived TNFalpha: glomerulotubular communication in IgA nephropathy. Kidney Int 2005;67:602-612.

7 Jevnikar AM, Brennan DC, Singer GG, Heng JE, Maslinski W, Wuthrich RP, Glimcher LH, Kelley VE: Stimulated kidney tubular epithelial cells express membrane associated and secreted TNF alpha. Kidney Int 1991;40:203-211.

-8 Dong X, Swaminathan S, Bachman LA, Croatt AJ, Nath KA, Griffin MD: Resident dendritic cells are the predominant TNF-secreting cell in early renal ischemia-reperfusion injury. Kidney Int 2007;71:619-628.

-9 Lai KN, Leung JC, Chan LY, Saleem MA, Mathieson PW, Lai FM, Tang SC: Activation of podocytes by mesangialderived TNF-alpha: glomerulo-podocytic communication in IgA nephropathy. Am J Physiol Renal Physiol 2008;294:F945-F955.

10 Awad AS, Rouse MD, Khutsishvili K, Huang L, Bolton WK, Lynch KR, Okusa MD: Chronic sphingosine 1-phosphate 1 receptor activation attenuates early-stage diabetic nephropathy independent of lymphocytes. Kidney Int 2011;79:1090-1098.

11 Fornoni A, Ijaz A, Tejada T, Lenz 0: Role of inflammation in diabetic nephropathy. Curr Diabetes Rev 2008;4: 10-17.

12 Navarro-Gonzalez JF, Mora-Fernandez C: The role of inflammatory cytokines in diabetic nephropathy. J Am Soc Nephrol 2008;19:433-442.

13 Ohta MY, Nagai Y, Takamura T, Nohara E, Kobayashi K: Inhibitory effect of troglitazone on tumor necrosis factor alpha-induced expression of monocyte chemoattractant protein-1 in human mesangial cells. Metabolism 2000;49:163-166.

14 Tesch GH: MCP-1/CCL2: a new diagnostic marker and therapeutic target for progressive renal injury in diabetic nephropathy. Am J Physiol Renal Physiol 2008;294:F697-F701.

$>15$ Ruster C, Wolf G: The role of chemokines and chemokine receptors in diabetic nephropathy. Front Biosci 2008; 13:944-955.

16 Tarabra E, Giunti S, Barutta F, Salvidio G, Burt D, Deferrari G, Gambino R, Vergola D, Pinach S, Perin PC, Camussi G, Gruden G: Effect of the monocyte chemoattractant protein-1/CC chemokine receptor 2 system on nephrin expression in streptozotocin-treated mice and human cultured podocytes. Diabetes 2009;58:2109-2118.

17 Lee EY, Chung CH, Khoury CC, Yeo TK, Pyagay PE, Wang A, Chen S: The monocyte chemoattractant protein-1/ CCR2 loop, inducible by TGF-beta, increases podocyte motility and albumin permeability. Am J Physiol Renal Physiol 2009;297:F85-F94.

18 Navarro JF, Milena FJ, Mora C, Leon C, Claverie F, Flores C, Garcia J: Tumor necrosis factor-alpha gene expression in diabetic nephropathy: relationship with urinary albumin excretion and effect of angiotensin-converting enzyme inhibition. Kidney Int Suppl 2005;S98-S102.

19 Lee EY, Chung CH, Kim JH, Joung HJ, Hong SY: Antioxidants ameliorate the expression of vascular endothelial growth factor mediated by protein kinase C in diabetic podocytes. Nephrol Dial Transplant 2006;21:1496-1503.

-20 Chen S, Kasama Y, Lee JS, Jim B, Marin M, Ziyadeh FN: Podocyte-derived vascular endothelial growth factor mediates the stimulation of alpha3(IV) collagen production by transforming growth factor-beta1 in mouse podocytes. Diabetes 2004;53:2939-2949.

-21 Sung SH, Ziyadeh FN, Wang A, Pyagay PE, Kanwar YS, Chen S: Blockade of vascular endothelial growth factor signaling ameliorates diabetic albuminuria in mice. J Am Soc Nephrol 2006;17:3093-3104.

-22 Wang A, Ziyadeh FN, Lee EY, Pyagay PE, Sung SH, Sheardown SA, Laping NJ, Chen S: Interference with TGF-beta signaling by Smad3-knockout in mice limits diabetic glomerulosclerosis without affecting albuminuria. Am J Physiol Renal Physiol 2007;293:F1657-F1665.

23 Berridge MV, Herst PM, Tan AS: Tetrazolium dyes as tools in cell biology: new insights into their cellular reduction. Biotechnol Annu Rev 2005;11:127-152.

24 Rao VH, Meehan DT, Delimont D, Nakajima M, Wada T, Gratton MA, Cosgrove D: Role for macrophage metalloelastase in glomerular basement membrane damage associated with alport syndrome. Am J Pathol 2006; 169:32-46.

25 Doublier S, Lupia E, Catanuto P, Periera-Simon S, Xia X, Korach K, Berho M, Elliot SJ, Karl M: Testosterone and 17beta-estradiol have opposite effects on podocyte apoptosis that precedes glomerulosclerosis in female estrogen receptor knockout mice. Kidney Int 2011;79:404-413. 
-26 Rosa AC, Rattazzi L, Miglio G, Collino M, Fantozzi R: Angiotensin II induces tumor necrosis factor-alpha expression and release from cultured human podocytes. Inflamm Res 2012;61:311-317.

27 Bruggeman LA, Drawz PE, Kahoud N, Lin K, Barisoni L, Nelson PJ: TNFR2 interposes the proliferative and NF-kappaB-mediated inflammatory response by podocytes to TNF-alpha. Lab Invest 2011;91:413-425.

-28 Hoffmann U, Bergler T, Rihm M, Pace C, Kruger B, Rummele P, Stoelcker B, Banas B, Mannel DN, Kramer BK: Upregulation of TNF receptor type 2 in human and experimental renal allograft rejection. Am J Transplant 2009;9:675-686.

29 Ueda A, Okuda K, Ohno S, Shirai A, Igarashi T, Matsunaga K, Fukushima J, Kawamoto S, Ishigatsubo Y, Okubo T: NF-kappa B and Sp1 regulate transcription of the human monocyte chemoattractant protein-1 gene. J Immunol 1994;153:2052-2063.

-30 Gruden G, Setti G, Hayward A, Sugden D, Duggan S, Burt D, Buckingham RE, Gnudi L, Viberti G: Mechanical stretch induces monocyte chemoattractant activity via an NF-kappaB-dependent monocyte chemoattractant protein-1-mediated pathway in human mesangial cells: inhibition by rosiglitazone. J Am Soc Nephrol 2005; 16:688-696.

-31 Gohda T, Niewczas MA, Ficociello LH, Walker WH, Skupien J, Rosetti F, Cullere X, Johnson AC, Crabtree G, Smiles AM, Mayadas TN, Warram JH, Krolewski AS: Circulating TNF receptors 1 and 2 predict stage 3 CKD in type 1 diabetes. J Am Soc Nephrol 2012;23:516-524.

-32 Niewczas MA, Gohda T, Skupien J, Smiles AM, Walker WH, Rosetti F, Cullere X, Eckfeldt JH, Doria A, Mayadas TN, Warram JH, Krolewski AS: Circulating TNF receptors 1 and 2 predict ESRD in type 2 diabetes. J Am Soc Nephrol 2012;23:507-515.

33 Omote K, Gohda T, Murakoshi M, Sasaki Y, Kazuno S, Fujimura T, Ishizaka M, Sonoda Y, Tomino Y: Role of the TNF pathway in the progression of diabetic nephropathy in KK-A(y) mice. Am J Physiol Renal Physiol 2014; 306:F1335-F1347.

34 Palladino MA, Bahjat FR, Theodorakis EA, Moldawer LL: Anti-TNF-alpha therapies: the next generation. Nat Rev Drug Discov 2003;2:736-746.

-35 Grund EM, Kagan D, Tran CA, Zeitvogel A, Starzinski-Powitz A, Nataraja S, Palmer SS: Tumor necrosis factoralpha regulates inflammatory and mesenchymal responses via mitogen-activated protein kinase kinase, p38, and nuclear factor kappaB in human endometriotic epithelial cells. Mol Pharmacol 2008;73:1394-1404.

-36 Bian ZM, Elner SG, Yoshida A, Elner VM: Differential involvement of phosphoinositide 3-kinase/Akt in human RPE MCP-1 and IL-8 expression. Invest Ophthalmol Vis Sci 2004;45:1887-1896.

37 Pincheira R, Castro AF, Ozes ON, Idumalla PS, Donner DB: Type 1 TNF receptor forms a complex with and uses Jak2 and c-Src to selectively engage signaling pathways that regulate transcription factor activity. J Immunol 2008;181:1288-1298.

-38 Noiri E, Kuwata S, Nosaka K, Tokunaga K, Juji T, Shibata Y, Kurokawa K: Tumor necrosis factor-alpha mRNA expression in lipopolysaccharide-stimulated rat kidney. Chronological analysis of localization. Am J Pathol 1994;144:1159-1166.

-39 Gao G, Zhang B, Ramesh G, Betterly D, Tadagavadi RK, Wang W, Reeves WB: TNF-alpha mediates increased susceptibility to ischemic AKI in diabetes. Am J Physiol Renal Physiol 2013;304:F515-F521.

40 Liu J, Zhao Z, Willcox MD, Xu B, Shi B: Multiplex bead analysis of urinary cytokines of type 2 diabetic patients with normo- and microalbuminuria. J Immunoassay Immunochem 2010;31:279-289.

-41 Ristola M, Arpiainen S, Saleem MA, Holthofer H, Lehtonen S: Transcription of nephrin-Neph3 gene pair is synergistically activated by WT1 and NF-kappaB and silenced by DNA methylation. Nephrol Dial Transplant 2012;27:1737-1745.

42 Yamauchi K, Takano Y, Kasai A, Hayakawa K, Hiramatsu N, Enomoto N, Yao J, Kitamura M: Screening and identification of substances that regulate nephrin gene expression using engineered reporter podocytes. Kidney Int 2006;70:892-900.

43 Kalantarinia K, Awad AS, Siragy HM: Urinary and renal interstitial concentrations of TNF-alpha increase prior to the rise in albuminuria in diabetic rats. Kidney Int 2003;64:1208-1213.

-44 Chow FY, Nikolic-Paterson DJ, Ozols E, Atkins RC, Rollin BJ, Tesch GH: Monocyte chemoattractant protein-1 promotes the development of diabetic renal injury in streptozotocin-treated mice. Kidney Int 2006;69:73-80.

$\checkmark 45$ Awad AS, Kinsey GR, Khutsishvili K, Gao T, Bolton WK, Okusa MD: Monocyte/macrophage chemokine receptor CCR2 mediates diabetic renal injury. Am J Physiol Renal Physiol 2011;301:F1358-F1366.

$\checkmark 46$ Chow FY, Nikolic-Paterson DJ, Atkins RC, Tesch GH: Macrophages in streptozotocin-induced diabetic nephropathy: potential role in renal fibrosis. Nephrol Dial Transplant 2004;19:2987-2996.

-47 Burt D, Salvidio G, Tarabra E, Barutta F, Pinach S, Dentelli P, Camussi G, Perin PC, Gruden G: The monocyte chemoattractant protein-1/cognate CC chemokine receptor 2 system affects cell motility in cultured human podocytes. Am J Pathol 2007;171:1789-1799.

-48 Setti G, Hayward A, Dessapt C, Barone F, Buckingham R, White K, Bilous R, Hiroshi K, Gruden G, Viberti G, Gnudi L: Peroxisome proliferator-activated receptor-gamma agonist rosiglitazone prevents albuminuria but not glomerulosclerosis in experimental diabetes. Am J Nephrol 2010;32:393-402. 